\title{
Challenges of implementing competency-based medical education postgraduate training programs: the issue of context
}

\section{Desafíos de la implementación de programas de formación de posgrado en educación médica basada en competencias: la cuestión del contexto}

Marcio M. Gomes ${ }^{1,2}$, Linda S. Snell 1,3

\begin{abstract}
Introduction: Competency-based medical education (CBME) is being adopted worldwide. The aim of this paper is to discuss the evolution of CBME and address some perceived challenges in CBME curriculum development and implementation in postgraduate (residency) medical education. Methods: This is an opinion paper based on lived experiences and personal beliefs. The authors have professional training in medical education and are actively involved in CBME research, curriculum development and implementation around the world. Results: The issue of local and system-wide context seems to be of particular importance to individuals, programs, institutions, governing bodies and other stakeholders involved in the development and implementation of CBME programs. CBME has evolved differently at different places, and there are concerns regarding the fidelity of implementation. Stakeholders have been dealing with challenging questions in their CBME journeys, which reflect the varied, complex and dynamic nature of health and education systems. Recently, scholars have established core components of any CBME program. Discussion and conclusions: CBME design should benefit from ground-up strategies that consider the local context. It is essential to approach implementation with a quality improvement lens and pay special attention to the fidelity and integrity of the core CBME components.
\end{abstract}

Keywords: Competence; curriculum development; outcome; fidelity; implementation.

\section{Resumen}

Introducción: la educación médica basada en competencias (CBME) se está adoptando en todo el mundo. El objetivo de este artículo es discutir la evolución de la CBME y abordar algunos desafíos percibidos en el desarrollo y la implementación de los estándares de CBME en la educación médica de posgrado (residencia). Métodos: este es un artículo de opinión basado en experiencias vividas y creencias personales. Los autores tienen formación profesional en educación médica y participan activamente en la investigación, el desarrollo y la implementación de programas de CBME en varios países. Resultados: la cuestión del contexto local y de todo el sistema parece ser de particular importancia para las personas, los programas, las instituciones, los órganos de gobierno y otras partes interesadas involucradas en el desarrollo y la implementación de los programas de CBME. La CBME ha evolucionado de manera diferente en diferentes lugares y existen preocupaciones con respecto a la fidelidad de la implementación. Las partes interesadas han estado lidiando con cuestiones difíciles en sus proyectos de CBME, que reflejan la naturaleza variada, compleja y dinámica de los sistemas de salud y educación. Recientemente, los académicos han establecido componentes centrales de cualquier programa CBME. Discusión y conclusiones: el diseño de la CBME debería beneficiarse de estrategias de base que consideren el contexto local. Sin embargo, es importante abordar la implementación con una lente de mejora de la calidad y prestar especial atención a la fidelidad e integridad de los componentes centrales de la CBME.

Palabras clave: educación médica basada en competencias; educación basada en resultados; desarrollo curricular; fidelidad de implementación.

Submission date: 2021-11-08 - Acceptance date: 2021-12-03

(1) Royal College of Physicians and Surgeons of Canada, Ottawa, Canada.

(2) University of Ottawa, Ottawa, Canada.

(3) Institute for Health Sciences Education, McGill University, Montreal, Canada.

Corresponding author:mgomes@royalcollege.ca 


\section{Introduction}

Competency-based medical education (CBME) is being adopted worldwide. CBME is a type of outcomes-based education in which the goal is to graduate competent physicians (Frank, 2010). This outcome was driven by societal changes and expectations, including the increased complexity of care, gaps in graduation, variability of physician practice, data on adverse events and increased requirement for oversight and accountability. In CBME, a competency framework usually details the desired abilities of physicians. These competencies are broad, involve a variety of abilities that are intertwined in the daily practice of physicians, and at times may be challenging to observe and assess (ten Cate $\&$ Scheele, 2007). Therefore, a later development in some CBME models was to structure training around so-called entrustable professional activities (EPA), which is defined as "An essential task of a discipline (profession, specialty, or subspecialty) that an individual can be trusted to perform without direct supervision in a given health care context, once sufficient competence has been demonstrated." (Englander et al., 2017) Guaranteeing that every physician can perform each and every task at a competent level makes the profession accountable to society, so the EPAs became units of instruction and assessment in several CBME models (ten Cate et al., 2010). Tailored and sequenced learning experiences facilitate the developmental acquisition of competency, with a deemphasis on time. Assessment focus shifted from test centres and classrooms to simulated and authentic work environments (ten Cate et al., 2010). The CBME enterprise then moved from restaurant napkins, conceptual models and isolated experiments to national curricula development and implementation. In this opinion paper, based on lived experiences and personal beliefs, the aim is to address some perceived challenges in CBME curriculum development and implementation in postgraduate medical education (PGME).

\section{CBME development and implementation}

The CBME movement has gained momentum around the world. Many jurisdictions embarked on this paradigmatic change to their approach to medical education and are undergoing multiyear projects of CBME implementation at a systems level. In trailblazer countries like Canada, the United States and the Netherlands, CBME has emerged from societal and academic discussions that eventually led to established national standard-setting bodies taking ownership and orchestrating its development and implementation. Although conceptually similar, CBME evolved differently at different places and brought different flavours. In Canada, CBME started with developing the CanMEDS competency framework in the early 1990 s as a standard for all postgraduate and continuing medical education programs. The framework evolved through pilot projects, national implementation of the framework, faculty development and is currently undergoing system-wide implementation of the full CBME model, Competence by Design (CBD). CBD itself is a multiyear project, with waves of disciplines going through curriculum development, gradually transitioning their residents' cohorts, and starting to evaluate the processes and outcomes.

In other parts of the world, like Latin America and the middle east, CBME development has been less systematic, with a variety of stakeholders, such as individual researchers institutions, specialty societies, regional jurisdictions and national bodies taking the lead of the CBME journey. Some tried to benefit from what was available, adopting "ready-to-use" competency frameworks and other curricular elements. In contrast, others tried to adapt existing frameworks or create an entirely new system. Some decided to embark on this enterprise using their resources, while others asked for assistance. For instance, the Royal College of Physicians and Surgeons of Canada (RCPSC) has established several international partnerships for CBME development at the postgraduate level. These partnerships include a myriad of activities, which have in common the ultimate goal of improving systems of PGME and include faculty development, continuing professional development, medical education conferences, research programs, assessment programs, certification exams, implementation of the CanMEDS competency framework, curriculum development, and program evaluation, recognition and accreditation.

It became clear from the start and from the outcomes of initial partnerships that the process needs to be "ground-up"; there is no "one size fits all". Some medical education systems have well-defined governance, structure and processes, while others were shaped as a byproduct of the dynamic socio-economic evolution of healthcare systems. Identifying and understanding the needs and the underlying homeostasis is essential for any successful endeavour, which evolves by brainstorming, discovery, and learning from within. Some difficult questions emerged from these discussions.

- How can a solo scholar initiate a CBME movement where there is no movement?

- How does a hospital develop faculty in places with no formal 'faculty', or how do you address resident wellness where there are no rules regarding duty hours?

- What does a high-performing academic institution do when the national accreditation body is enforcing outdated standards?

- How could a national specialty society enforce national educational standards when the opening (and maintenance) of new PGME programs is a political decision? 
- How do you promote equity, diversity and inclusion (EDI) where EDI is not (yet) an issue?

- How do you change resident selection and promotion or allow for variation in the duration of the training when service delivery relies on trainees as a workforce?

- How do you teach principles of equity and stewardship of health care resources when patient access to services is inequal within and across institutions?

- How should a national governing body implement change that will stop once a new government takes over?

Some of these questions might not apply to many of us or all programs, but if we honestly reflect, to a lesser or a greater extent, we can realise that at least tangentially, they touch us all. With such a variety of potential contexts, there is an expectation that CBME will evolve differently at different places. Unlike the structure and process "Flexnerian" model, which has lasted over a century, CBME is at its infancy, learning to walk (Caraccio et al., 2002). But if one wants CBME to last to the end of this century, it is crucial to determine the essential elements of a CBME program to allow its implementation in distinct contexts without losing its integrity. As is clear from natural selection, diversity is not part of the problem but part of the solution. In participatory decision-making, stakeholders also need to initially diverge, to discuss and explore their ideas and options. This process eventually generates anxiety and discomfort, what Kaner described as the "groan zone", in which "struggle is in the service of integration", allowing the understanding of different opinions and new possibilities can emerge (Kaner, 2014). It was in this confluent zone of distinct CBME models under implementation globally that education scholars worked with the International Competency-based Medical Education (ICBME) Collaborators to find common ground and described principles and commitments (Caraccio et al., 2016), a shared language (Englander et al., 2017), and the core components of CBME (Van Melle et al., 2019).

\section{The core components of CBME programs}

In outcomes-based education and curriculum development in general, we need to begin with the end in mind. The CBME end is competence, but to determine what competence means to society, we need to look at health needs first. Once the health needs of a community (a neighbourhood, a town, a country), are defined we can describe the scope of practice of physicians who deliver care to address those needs. And when we think of CBME in PGME, we need to define for every resident graduating from a given specialty in a given place the abilities they need to demonstrate and the activities they need to perform competently at the end of their training. The next step is to create a curriculum of tailored training experiences required to facilitate the developmental acquisition of those competencies and a program of assessment to support and verify that trainees acquired those abilities and can transition to unsupervised practice. In table 1 there is a summary of these core components of CBME programs. The next steps after curriculum development include curriculum implementation, program evaluation (fidelity of implementation and program outcomes), and continuous quality improvement cycles. Provided that the core components are integral, there should be room for adaptation and innovation in local contexts with distinct designs evolving over time (Van Melle et al., 2019).

Table 1: The core components of competency-based medical education (adapted from Van Melle et al., 2019).

\begin{tabular}{l|l}
\hline Outcome competencies & $\begin{array}{l}\text { Competencies required for practice are } \\
\text { clearly articulated. }\end{array}$ \\
\hline Sequenced progression & $\begin{array}{l}\text { Competencies and their developmental } \\
\text { markers are sequenced progressively. }\end{array}$ \\
\hline Tailored learning experiences & $\begin{array}{l}\text { Learning experiences facilitate the deve- } \\
\text { lopmental acquisition of competencies. }\end{array}$ \\
\hline instruction & $\begin{array}{l}\text { Teaching practices promote the deve- } \\
\text { lopmental acquisition of competencies. }\end{array}$ \\
\hline Programmatic assessment & $\begin{array}{l}\text { Assessment practices support and do- } \\
\text { cument the developmental acquisition } \\
\text { of competencies. }\end{array}$ \\
\hline
\end{tabular}

\section{The issue of context}

Competence is defined as "an array of abilities (knowledge, skills, and attitudes) across multiple domains or aspects of performance in a certain context" (Frank et al., 2010). The issue of context is integral to the competence of an individual but has vast implications for the system and the design of CBME programs. The contexts in rural Araucanía and downtown Santiago are distinct, as are the contexts in different countries and continents. And context includes a variety of known and unknown variables. Some known variables are societal health needs, healthcare delivery models, healthcare resources, medical education systems, stages of professionalization of medical education, political and institutional practices and stability, medical and educational culture and identity, to name a few. We cannot comment on specific unknown variables. Still, we can surely comment on the unknown influence of the dynamic interplay between all the known variables that create a unique environment. Even if we focus on a known variable, such as political and institutional stability, it is such a complex social dimension that we can hardly grasp its surface. We do not know how it will 
influence or be influenced by other factors in the equation, and we cannot predict how it will evolve. Take as an example the seemingly linear evolution of CBME in Canada described above. The description itself is a post hoc historical analysis. It was not intended to evolve this way from the beginning, and no one could predict that it would. Each phase of the process led to the other due to the dynamic interplay of system factors that were not under control by any single party.

\section{Reflections and the journey ahead of us}

One of the criticisms of CBME is that it is reductionist, reducing a complex phenomenon into its most basic or simple parts and omitting the natural intricacies of the practice of medicine. But human beings are reductionists by nature. We reduce because it is challenging to deal with complexity; it is impossible to account for the randomness of events that will occur along the way in dynamic environments (Taleb, 2007). Working on its parts does not mean that CBME as a whole is evolving by chance or uncontrolled. Each step of the way results from hard and deliberate work. But the action does not guarantee success; we can only decide the direction it takes. The ICBME Collaborators proposed principles and commitments that educators should abide by and demonstrate to advance CBME (Caraccio et al., 2016). The principles align with the core components described above, and the commitments include multiple aspects, from teaching and assessment to faculty development and program evaluation. We argue that maybe the most fundamental overarching commitment in CBME is to continuous quality improvement. The outcomes of medical training were suboptimal to society, and the medical education field is trying a variety of interventions as a response. We must wisely select and monitor the outcome, process and balancing measures while we pay attention to the fidelity and integrity of implementation. Diverse models have been tested at different places and, although we might not need to reinvent the wheel, the roads are unique and will take us to different destinations. The first iteration of core elements of CBME curricula are well delineated (Van Melle et al., 2019) and will follow its developmental trajectory, evolving as we get to know more about CBME practices and outcomes. The development of CBME needs to be from the ground-up, tailored to individual health care contexts and needs, constantly adapted as the context changes, and continuously create value to society. If we do it correctly, it will start at different points and evolve distinctly, bringing new flavours to medical education. Enjoy the ride. And accept that serendipity will play a huge role.

\section{Acknowledgements}

No funding was received. Authors Marcio Gomes (the University of Ottawa and RCPSC) and Linda Snell (McGill University and RCPSC) are RCPSC clinician educators. They have participated in several activities related to curriculum development and implementation in Canada, Latin America and elsewhere. Dr Gomes is the Regional Advisor for Latin America at Royal College International. Both authors participated in writing, reviewing and editing the manuscript.

There are no conflicts of interest.

\section{References}

Carraccio C, Wolfsthal SD, Englander R, Ferentz K \& Martin C. (2002). Shifting paradigms: from Flexner to competencies. Academic medicine 77, 361-367.

Carraccio C, Englander R, Van Melle E, Ten Cate O, Lockyer J, Chan MK, Frank JR, Snell LS \& International Competency-Based Medical Education Collaborators. (2016). Advancing competency-based medical education: a charter for clinician-educators. Academic medicine 91, 645-649.

Englander R, Frank JR, Carraccio C, Sherbino J, Ross S, Snell L \& ICBME Collaborators. (2017). Toward a shared language for competency-based medical education. Medical teacher 39, 582-587.

Frank JR, Snell LS, Cate OT, Holmboe ES, Carraccio C, Swing SR, Harris P, Glasgow NJ, Campbell C, Dath D, Harden RM, lobst W, Long DM, Mungroo R, Richardson DL, Sherbino J, Silver I, Taber S, Talbot M \& Harris KA. (2010). Competency-based medical education: theory to practice. Medical teacher 32, 638-645.

Kaner, S. (2014). Facilitator's Guide to Participatory Decision-Making (3rd ed.). Wiley. Accedido en: https://www.perlego.com/ book/2759962/facilitators-guide-to-participatory-decisionmaking-pdf el 10 de octubre de 2021.

Taleb NN. (2007). The black swan: The impact of the highly improbable. Random house. New York.

ten Cate O, Snell L. \& Carraccio C. (2010). Medical competence: the interplay between individual ability and the health care environment. Medical teacher 32, 669-675.

Van Melle E, Frank JR, Holmboe ES, Dagnone D, Stockley D, Sherbino J \& International Competency-based Medical Education Collaborators. (2019). A Core Components Framework for Evaluating Implementation of Competency-Based Medical Education Programs. Academic medicine 94,1002-1009. 